\title{
Insight into the Biological Activity of Hennosides-Glucosides Isolated from Lawsonia inermis (henna): Could They Be Regarded as Active Constituents Instead
}

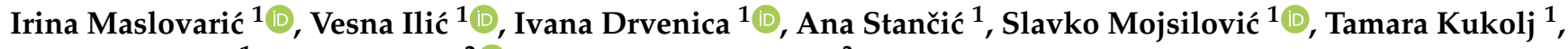 \\ Diana Bugarski ${ }^{1}$, Luciano Saso ${ }^{2}$ and Marcello Nicoletti ${ }^{3, *}$ \\ 1 Institute for Medical Research, University of Belgrade, Dr Subotića 4, POB 39, 11129 Belgrade 102, Serbia; \\ irina.maslovaric@imi.bg.ac.rs (I.M.); vesnai@imi.bg.ac.rs (V.I.); ivana.drvenica@imi.bg.ac.rs (I.D.); \\ ana_stancic@hotmail.com (A.S.); slavko@imi.bg.ac.rs (S.M.); tamara.kukolj@imi.bg.ac.rs (T.K.); \\ dianab@imi.bg.ac.rs (D.B.) \\ 2 Department of Physiology and Pharmacology "Vittorio Erspamer", Sapienza University of Rome, \\ Square Aldo Moro, 5, 00185 Rome, Italy; luciano.saso@uniroma1.it \\ 3 Department of Environmental Biology, Sapienza University of Rome, Square Aldo Moro, 5, 00185 Rome, Italy \\ * Correspondence: marcello.nicoletti@uniroma1.it
}

check for updates

Citation: Maslovarić, I.; Ilić, V.; Drvenica, I.; Stančić, A.; Mojsilović, S.; Kukolj, T.; Bugarski, D.; Saso, L.; Nicoletti, M. Insight into the Biological Activity of Hennosides-Glucosides Isolated from Lawsonia inermis (henna): Could They Be Regarded as Active Constituents Instead. Plants 2021, 10, 237. https://doi.org/10.3390/ plants10020237

Received: 11 December 2020

Accepted: 19 January 2021

Published: 26 January 2021

Publisher's Note: MDPI stays neutral with regard to jurisdictional claims in published maps and institutional affiliations.

Copyright: (c) 2021 by the authors. Licensee MDPI, Basel, Switzerland. This article is an open access article distributed under the terms and conditions of the Creative Commons Attribution (CC BY) license (https:/ / creativecommons.org/licenses/by/ $4.0 /)$.

\begin{abstract}
Henna is the current name of the dye prepared from the dry leaf powder of Lawsonia inermis (Lythraceae). Several studies have focused on the chemistry and pharmacology of the henna dyeing active compound, lawsone, obtained from the main constituents of leaves, hennosides, during the processing of plant material. However, knowledge regarding the biological activity of hennosides is largely lacking. In this paper, the redox activity of three hennoside isomers is reported. The prooxidative activity was confirmed by their ability to induce mild lysis of erythrocytes and to increase the level of methemoglobin at the concentration $\geq 500 \mu \mathrm{g} / \mathrm{mL}$. The antioxidant activity of hennosides (concentration $\geq 100 \mu \mathrm{g} / \mathrm{mL}$ ) was determined by FRAP and ABTS assays. At concentration of $500 \mu \mathrm{g} / \mathrm{mL}$, antioxidant activity of hennoside isomers was equivalent to $0.46 \pm 0.08,0.62 \pm 0.28$ and $0.35 \pm 0.03 \mathrm{mM} \mathrm{FeSO}_{4} \times 7 \mathrm{H}_{2} \mathrm{O}$, and $0.15 \pm 0.01,0.30 \pm 0.01$ and $0.09 \pm 0.01 \mathrm{mM}$ Trolox. Hennosides at $100 \mu \mathrm{g} / \mathrm{mL}$ concentration did not influence viability of human breast cancer cell lines MDA231 and MCF-7 and primary human peripheral blood and periodontal ligament-mesenchymal stem cells, but produced a modest increase in concentration of antioxidants in the cell culture supernatants. The evidenced antioxidant and pro-oxidant activities indicate their potential to act as redox balance regulator, which opens up the possibility of using hennosides in commercial phytomedicines.
\end{abstract}

Keywords: Lawsonia inermis; Lythraceae; glucosides; redox activity

\section{Introduction}

Lawsonia inermis L. (syn. L. alba o L. spinosa, family Lythraceae), vulgarly known as henna, hennè, shudi, madurang, manghati, madayantika and goranti, is a perennial shrub, well known from ancient times as a medicinal and dyeing plant [1]. Nowadays, because of its strong coloring properties, the use of dried henna leaf powder for hair coloring and the body-decorating process, "temporary tattoos", also known as mehndi $[2,3]$, on the skin has increased. In the US, direct application to the skin is not approved by the Food and Drug Administration [4]. Conversely, it is authorized and widely available as a coloring agent for hair across the globe, including in the US [5]. The coloring action of red henna is due to lawsone, 2-hydroxy-1,4-naphtoquinone. Nonetheless, to obtain the dying effect of henna, the leaves must be treated until the principal active ingredient, lawsone, is able to react via Michael reaction with keratin in the skin and hair, resulting in a permanent dye stain:

$$
\mathrm{C}_{9} \mathrm{H}_{5} \mathrm{O}_{2}-\mathrm{C}=\mathrm{O}+{ }_{2} \mathrm{HN}-\text { Keratin } \rightarrow \mathrm{C}_{9} \mathrm{H}_{5} \mathrm{O}_{2}-\mathrm{C}=\mathrm{N}-\text { Keratin }+\mathrm{H}_{2} \mathrm{O}
$$


There is evidence, however, that lawsone, an aglycone, is an artifact arising from the oxidative transformation of the primary glycosidic constituents during the processing of plant material to obtain the dye [6]. The relation between glucosides and aglycone is common in natural products chemistry. Therefore, a preliminary treatment is necessary to convert the hennosides (glucosides), present originally in the raw material, into an active herbal dying principle, lawsone [7]. Conversion of hennosides into the unique aglycone requires that henna powder be soaked in mildly acidified solution for 6 to $24 \mathrm{~h}$ before use. Hennosides are three isomer glucosides, where each of the hydroxyls, derived from the interconversion of the two keto-enol forms of the naphtoquinone structure, can be glycosylated, leading to hennoside isomerism. The aglycone, derived from their hydrolysis, is then converted by oxidation into lawsone, the dying active compound (Figure 1) [7]. The henna drug content is usually referred to as the lawsone content, but as demonstrated [7], lawsone, as a free molecule, is absent in the raw material, and hennosides, precursors of henna, that are co-occurring in the activity with lawsone, could be regarded as active constituents instead [8] and serve to evaluate any biological activity of henna leaves exploited in traditional medicine in many countries.

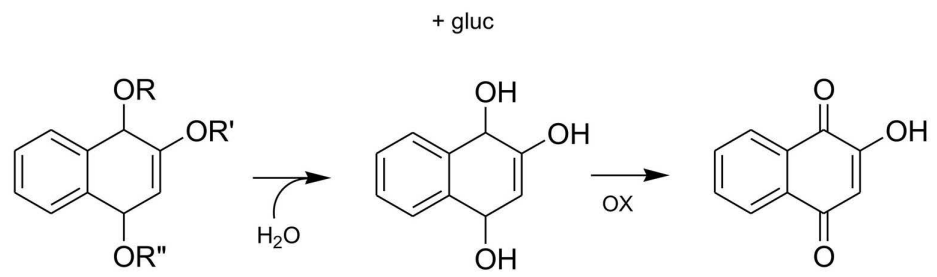

$$
\begin{array}{ll}
R=\text { gluc } & R^{\prime}=R^{\prime \prime}=H \\
R^{\prime}=\text { gluc } & R=R^{\prime \prime}=H \\
R^{\prime \prime}=\text { gluc } & R=R^{\prime}=H
\end{array}
$$

Figure 1. Conversion of hennosides (isomerglucosides) into lawsone (aglycone).

In fact, although the cosmetic use of henna has obscured its medicinal importance, the use of the leaves is well present in all the cultures producing or using the plant. The Ebers Papyrus, dated to about 1550 B.C., is one of the oldest known scrolls and the main source of herbal knowledge of medicine in ancient Egypt [9]. Henna is reported as a pharmacologically important plant with significant in vitro and in vivo biological activities. Several pharmacological activities such as antibacterial, antioxidant, anti-inflammatory and anticancer properties have been documented, of which the antioxidant and antimicrobial activities have been most thoroughly investigated [1]. In the dried leaves, besides lawsone, other compounds present like, polyphenols and glucides are also co-occurring in the activity of henna [8]. However, the information about its most particular constituents is insufficient. In this paper, we evaluate the biological properties, redox, and cytotoxic activity of hennosides, designated A, B and C, respectively. Unlike lawsone, which is easily chemically produced, hennosides are difficult to obtain in pure form, and often they are referred to as lawsone. This study could be also of ethnopharmacological interest, to confirm or reconsider the use of henna in traditional medicine through the definition of hennoside activity, and it could serve as a valuable source of information for carrying out further studies on this plant in future.

\section{Results}

\subsection{Antioxidant Activity of Hennosides}

When hennosides were dissolved in $0.9 \% \mathrm{NaCl}$, both FRAP (ferric ion reducing antioxidant power) and ABTS (2,2'-azino-bis(3-ethylbenzothiazoline-6-sulfonic acid) assays showed antioxidant activity at hennoside concentration $\geq 100 \mu \mathrm{g} / \mathrm{mL}$ (Figure 2, Table S1). The highest antioxidant activity was confirmed for hennoside B with both assays. When 
hennosides were dissolved in complete cell culture Dulbecco's Modified Eagle Medium containing $10 \%$ fetal calf serum (D'MEM $/ 10 \% \mathrm{FCS}$ ), their antioxidant capacity could not be measured with ABTS assay. This result demonstrated the high antioxidant capacity of the cell culture medium, indicating masking of antioxidant activity of hennosides by cell culture medium. The FRAP assay showed the antioxidant activity of hennosides in the cell culture media at hennoside concentration $\geq 100 \mu \mathrm{g} / \mathrm{mL}$ (Figure 2; Table S1).

a)

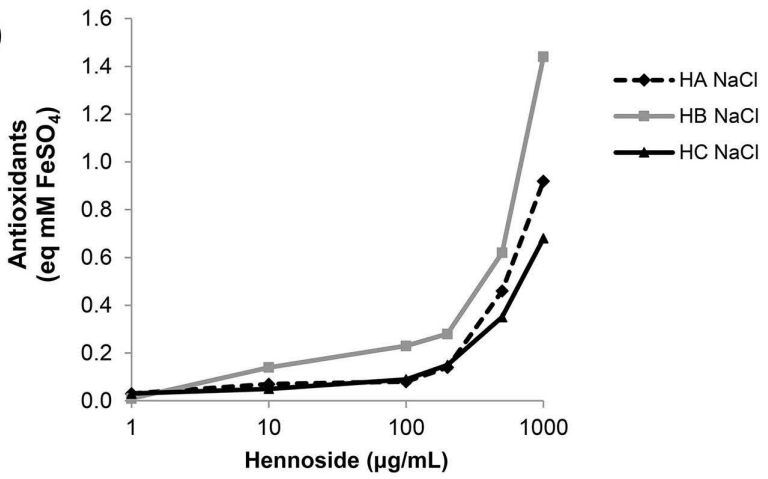

c)

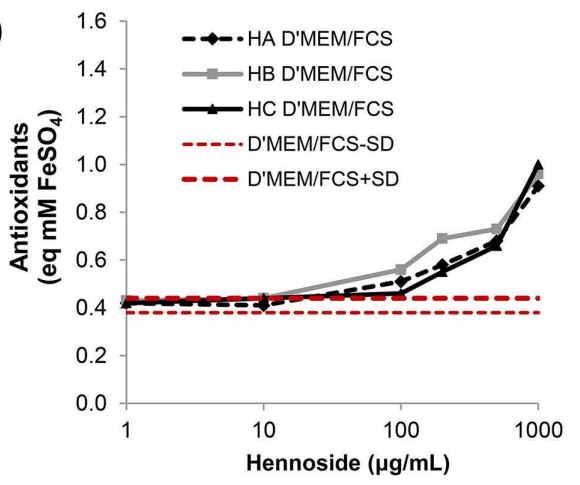

b)

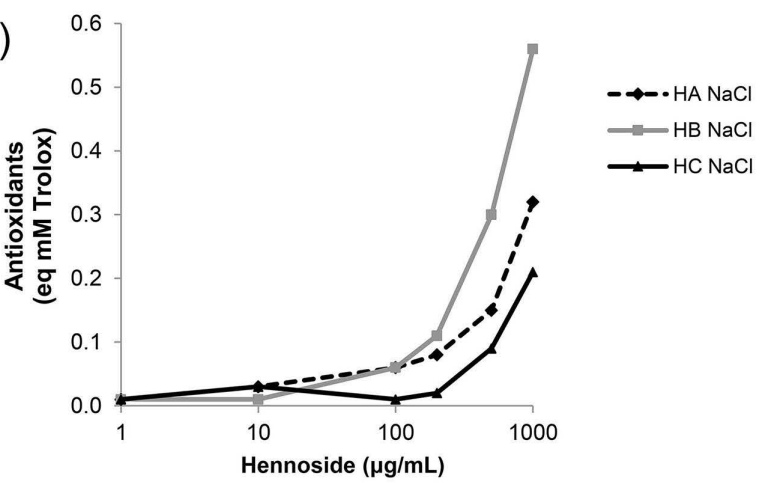

d)

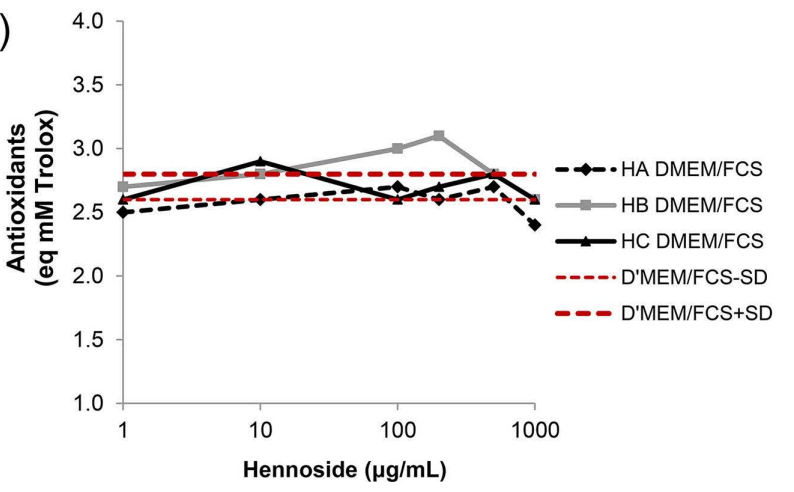

Figure 2. Antioxidant activity of hennosides in isotonic $\mathrm{NaCl}$ and Dulbecco's Modified Eagle Medium supplemented with $10 \%$ fetal calf serum (D'MEM/FCS). Antioxidant activity measured by FRAP $(\mathbf{a}, \mathbf{c})$ and ABTS $(\mathbf{b}, \mathbf{d})$ assay. HA-hennoside A; HB —hennoside B; HC—hennoside C; $\mathrm{NaCl}-0.9 \% \mathrm{NaCl}$; D'MEM/FCS: D'MEM cell culture medium supplemented with $10 \% \mathrm{FCS} ;(\mathbf{a}, \mathbf{b})$ Values represent the concentration of antioxidants diluted in $0.9 \% \mathrm{NaCl}$. (c,d) Values represent the concentration of antioxidants diluted in D'MEM + 10\%FCS; Red lines indicate mean-1SD (D'MEM/FCS - SD) to mean + $1 \mathrm{SD}\left(\mathrm{D}^{\prime} \mathrm{MEM} / \mathrm{FCS}+\mathrm{SD}\right)$ range of antioxidant concentration in D'MEM/FCS.

\subsection{Effect of Hennosides on Erythrocyte lysis}

The extent of hemolysis was determined by measuring the absorbance (optical density) at $540 \mathrm{~nm}\left(\mathrm{OD}_{540}\right)$ of supernatants obtained after centrifugation of erythrocyte suspension incubated with hennosides. A mild hemolysis was recorded in the presence of hennosides at $\geq 500 \mu \mathrm{g} / \mathrm{mL}$ concentration (Figure 3, Table S2). Furthermore, the results showed the lack of hemolytic effect of dimethyl sulfoxide (DMSO), used as a stock solution for hennosides, in the concentrations applied. 

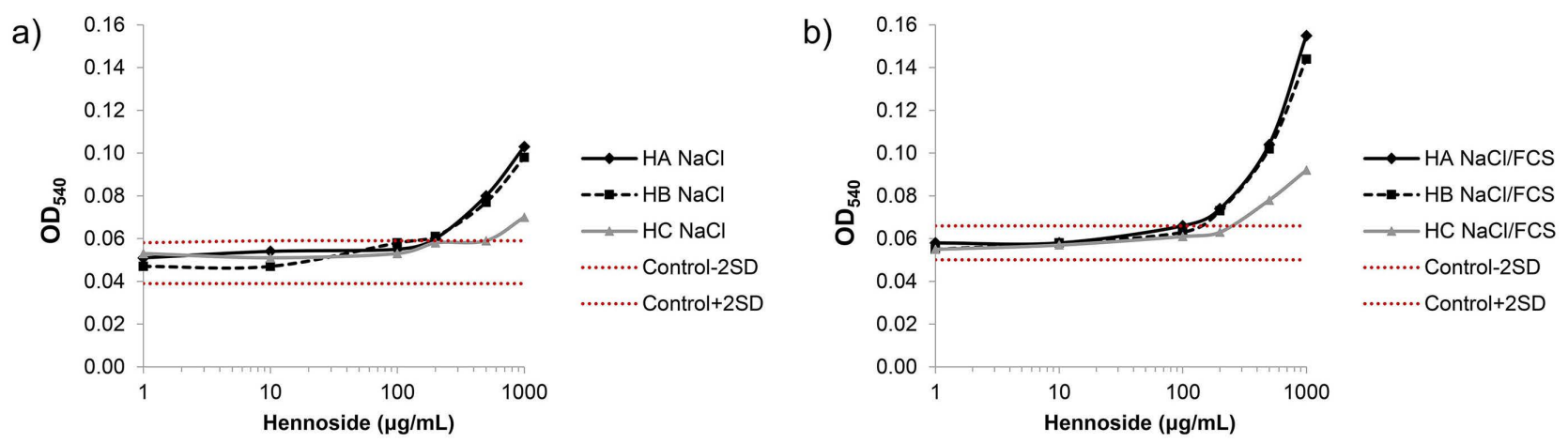

Figure 3. Hennoside-induced lysis of erythrocytes resuspended in (a) $0.9 \% \mathrm{NaCl}$ and (b) $0.9 \% \mathrm{NaCl}$ containing $10 \%$ FCS $(\mathrm{NaCl} / \mathrm{FCS})$. The hemolysis was followed based on the optical density at $540 \mathrm{~nm}\left(\mathrm{OD}_{540}\right)$ values of supernatants obtained after centrifugation of erythrocyte suspension. HA — hennoside A; HB — hennoside B; $\mathrm{HC}$ - hennoside C; $\mathrm{NaCl}$-hennosides and erythrocytes diluted in $0.9 \% \mathrm{NaCl} ; \mathrm{NaCl} / \mathrm{FCS}$ - hennosides and erythrocytes diluted in $0.9 \% \mathrm{NaCl}$ containing $10 \% \mathrm{FCS}$. Red lines indicate mean - 2SD (control - 2SD) to mean + 2SD (control + 2SD) range of control i.e., spontaneous lysis of erythrocytes incubated in $0.9 \% \mathrm{NaCl}(\mathbf{a})$ and (b) $0.9 \% \mathrm{NaCl} / \mathrm{FCS}$ without hennosides.

The highest concentrations, $\geq 200 \mu \mathrm{g} / \mathrm{mL}$, of hennosides in $0.9 \% \mathrm{NaCl}$ changed the erythrocyte color from bright red to a dark red-violet color, which reflected the change in hemoglobin molecules. Some hennoside-induced hemoglobin structural changes are described in Section 2.3. Conversely, when erythrocytes and hennosides were diluted in $0.9 \% \mathrm{NaCl} / 10 \% \mathrm{FCS}$, the hennoside-induced erythrocyte color change was detected only at the concentration of $1000 \mu \mathrm{g} / \mathrm{mL}$ (Figure 4).
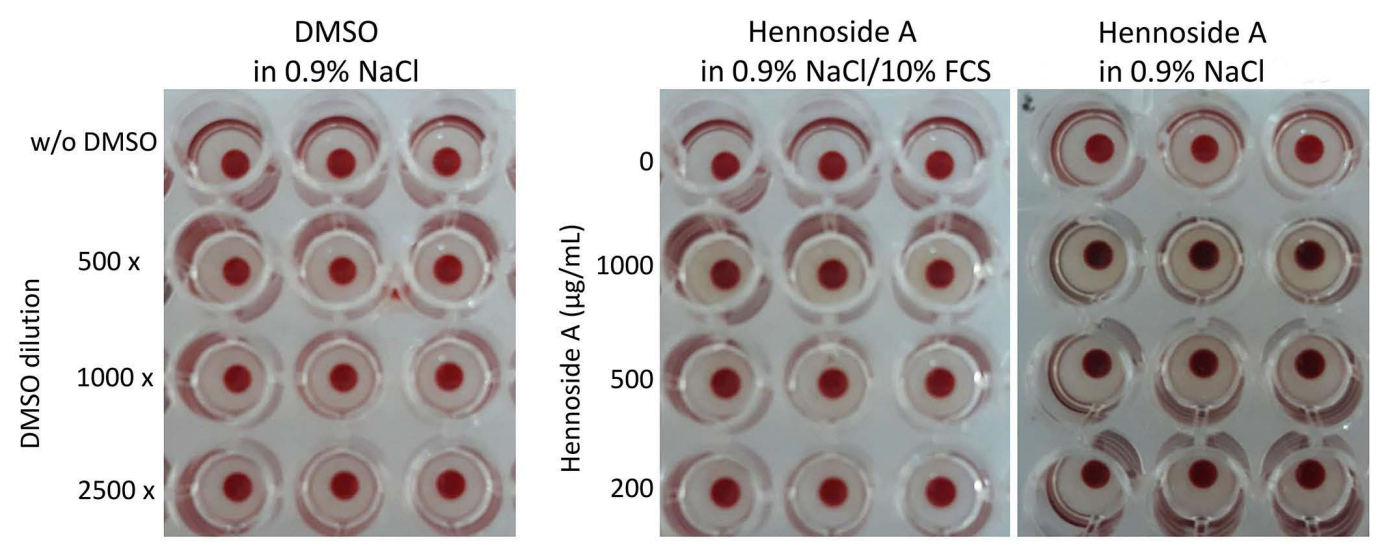

Figure 4. Hennoside-induced changes in color of erythrocytes. The image depicts the remaining non-lysed/intact erythrocytes after 90 min incubation, at $37^{\circ} \mathrm{C}$ with hennosides diluted in $0.9 \% \mathrm{NaCl}$ or $0.9 \% \mathrm{NaCl}$ containing $10 \%$ FCS. DMSO diluted in $0.9 \%$ is used as a control. The results show non-hemolytic effect of DMSO.

\subsection{Effect of Hennosides on Hemoglobin}

The pro-oxidative activity of hennosides was evaluated based on their capacity to modulate Vis spectral characteristics of outdated hemoglobin $(\mathrm{Hb})$ in solution. The effect was dependent on hennoside isoform and solvent type used. VIS absorption spectroscopy has been employed as a universal method for investigating the structural changes of hemoglobin [10-12]. When 390-750 $\mathrm{nm}$ absorption spectrum of outdated $\mathrm{Hb}$ was analyzed, the absorption bands at 403-405, 541, $576 \mathrm{~nm}$, characteristic of native, oxyhemoglobin, are identified. The porphyrin ring of the heme group showed an intensive absorption maximum at 403-407, i.e., the Soret band, and two absorption maxima at 541 and $577 \mathrm{~nm}$ $(\alpha$ and $\beta$ ) were derived from oxyhemoglobin. The absorbance at $630 \mathrm{~nm}$ originated from methemoglobin (oxidized, $\mathrm{Fe}^{3+} \mathrm{Hb}$ ), and indicates the partially oxidized hemoglobin (Figure 5, dashed line). Hennosides in concentration of $500 \mu \mathrm{g} / \mathrm{mL}$ showed changes 
towards further oxidation/denaturation of $\mathrm{Hb}$. Markedly changed absorption spectrum can be noticed: (1) a blue spectral shift, toward shorter wavelength, of the $\mathrm{Hb}$, (2) the decrease of $\Delta \alpha / \Delta \beta$ value (indicates the transformation of $\mathrm{Hb}$ molecule to the oxidized form, (3) an increase in the ratio between the absorbance of Soret band and the absorbance at 577 (reflects the presence of free heme and the breakdown of $\mathrm{Hb}$ molecule), and (4) an increase in the absorbance value at $630 \mathrm{~nm}$ (indicates an increased methemoglobin level) (Figure 5, Table 1). The effect of hennosides was less pronounced in isotonic $\mathrm{NaCl}$ containing $10 \%$ FCS than in isotonic $\mathrm{NaCl}$ solution alone, establishing the protective role of the serum on $\mathrm{Hb}$ status.

a

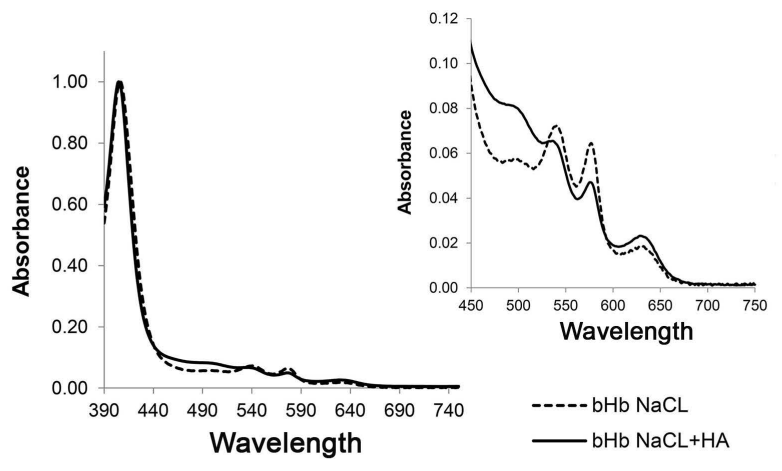

C

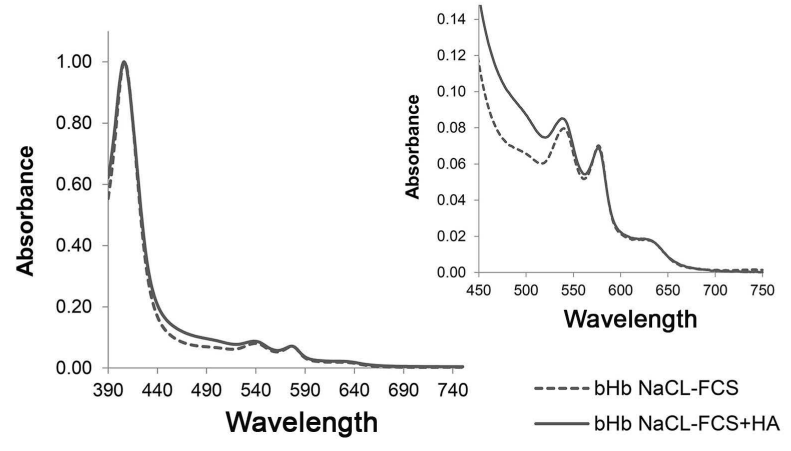

b

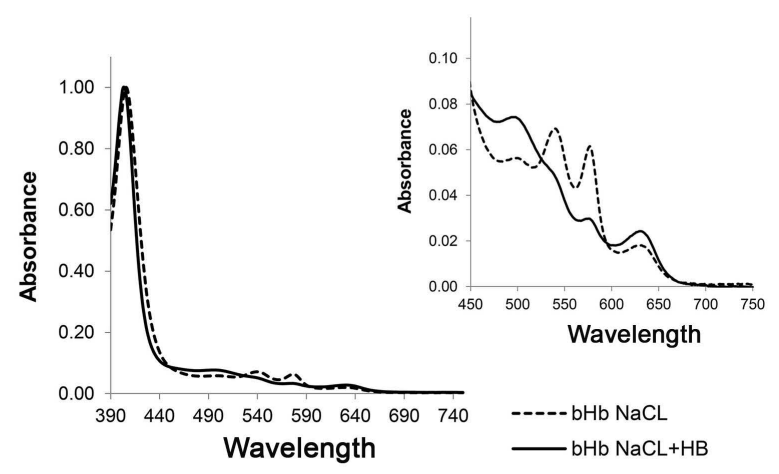

d

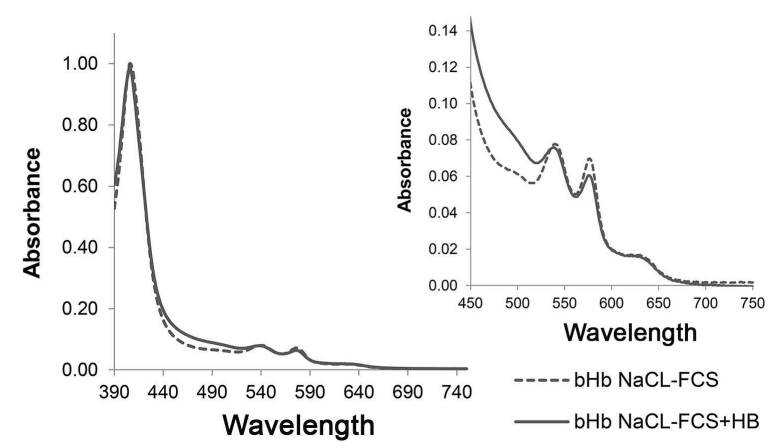

Figure 5. Hennoside-induced changes of Vis spectral characteristic (390-750 nm; zoom region 450-750 nm) of hemoglobin in solution. (a,c) $500 \mu \mathrm{g} / \mathrm{mL}$ of hennoside $\mathrm{A} ;(\mathbf{c}, \mathbf{d}) 500 \mu \mathrm{g} / \mathrm{mL}$ of hennoside B; (a,b) diluent $0.9 \% \mathrm{NaCl}(\mathrm{NaCl}) ;(\mathbf{c}, \mathbf{d})$ diluent $0.9 \% \mathrm{NaCl}$ containing $10 \% \mathrm{FCS}$ ( $\mathrm{NaCl}-\mathrm{FCS})$.

Table 1. Effect of $500 \mu \mathrm{g} / \mathrm{mL}$ of hennosides A and B on Vis spectral characteristics of hemoglobin.

\begin{tabular}{ccccc}
\hline & Soret Band & $\boldsymbol{\Delta} \boldsymbol{\alpha} / \boldsymbol{\Delta} \boldsymbol{\beta}$ & OD $_{\text {Soret }} / \mathbf{O D}_{\mathbf{5 7 5}}$ & OD $_{\mathbf{6 3 0}}$ \\
\hline $\mathrm{Hb}$ in $\mathrm{NaCl}$ & 406 & 0.70 & 15.6 & 0.018 \\
$\mathrm{Hb}$ in NaCl + HA & 405 & 0.29 & 20.4 & 0.026 \\
$\mathrm{Hb}$ in NaCl-FCS & 407 & 0.64 & 14.1 & 0.019 \\
$\mathrm{Hb}$ in NaCl-FCS + HA & 406 & 0.54 & 14.1 & 0.022 \\
\hline $\mathrm{Hb}$ in NaCl & 406 & 0.69 & 15.9 & 0.020 \\
$\mathrm{Hb}$ in NaCl + HB & 403 & 0.00 & 30.3 & 0.028 \\
$\mathrm{Hb}$ in NaCl-FCS & 406 & 0.71 & 13.9 & 0.019 \\
$\mathrm{Hb}$ in NaCl-FCS + HB & 406 & 0.46 & 15.6 & 0.020 \\
\hline
\end{tabular}

HA-hennoside A; HB-hennoside B; $\Delta \alpha / \Delta \beta=\left(\mathrm{OD}_{577}-\mathrm{OD}_{560}\right) /\left(\mathrm{OD}_{541}-\mathrm{OD}_{560}\right) ; \mathrm{NaCl}-0.9 \% \mathrm{NaCl} ; \mathrm{NaCl}-\mathrm{FCS}-$ $0.9 \% \mathrm{NaCl}$ supplemented with $10 \% \mathrm{FCS}$.

The effect of hennosides on methemoglobin formation, i.e., an increase in absorbance (optical density) at $630 \mathrm{~nm}\left(\mathrm{OD}_{630}\right)$, was analyzed in a wide concentration range (1-1000 $\mu \mathrm{g} / \mathrm{mL}$ ) (Figure 6, Table S3). In isotonic $\mathrm{NaCl}$ solution, the $\mathrm{Hb} \mathrm{OD}_{630}$ values 
gradually increased at the concentration $\geq 500 \mu \mathrm{g} / \mathrm{mL}$ for each hennoside tested. In $\mathrm{NaCl}$ with $10 \%$ FCS the pronounced effect was detected only for hennoside A.
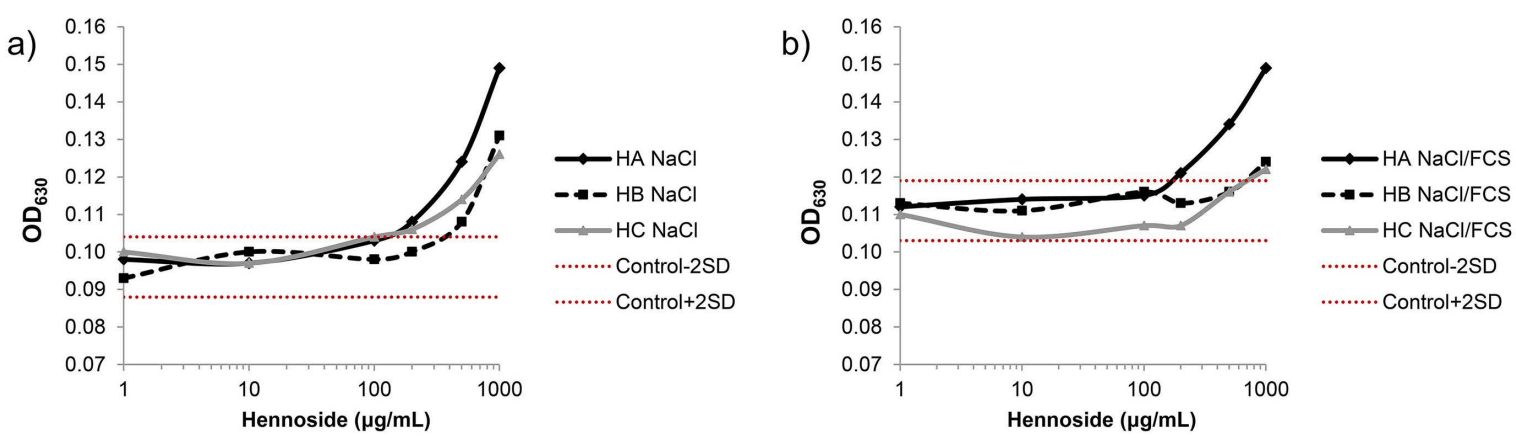

Figure 6. Hennoside-induced methemoglobin formation. Methemoglobin measurement based on an increase in $\mathrm{OD}_{630}$ values. (a) diluent $0.9 \% \mathrm{NaCl}(\mathrm{NaCl}) ;$ (b) diluent $0.9 \% \mathrm{NaCl}$ containing $10 \% \mathrm{FCS}(\mathrm{NaCl} / \mathrm{FCS})$. Dotted red lines represent mean value $\pm 2 \mathrm{SD}$ range for the control, i.e., spontaneously formed methemoglobin.

\subsection{Effect of Hennosides on Cell Viability}

After 24, 48 and $72 \mathrm{~h}$, the viability of two breast cancer cell lines (MCF-7 and MDA 231) and two primary human mesenchymal stem cells (PDL-MSC and PB-MSC) was recorded by MTT (thiazolyl blue tetrazolium bromide) assay. Hennosides were used at a final concentration of $100 \mu \mathrm{g} / \mathrm{mL}$. This concentration was chosen based on our experiment performed on erythrocytes and isolated $\mathrm{Hb}$, where at this concentration of hennosides, neither erythrocyte lysis nor methemoglobin formation was assessed (Figures 3 and 6). The concentration of $100 \mu \mathrm{g} / \mathrm{mL}$ was also the lowest concentration found to be responsible for antioxidant activity (Figure 2). The results showed a time-dependent change in the capacity of PB-MSC and MDA 231 cells, cultivated only in the cell culture medium, to reduce MTT. The enhancement in reduction of MTT was not detected in MCF-7 and PDL-MSC; the latter was compliant with our previous results [13] (Figure 7). We found no cytotoxicity for a given concentration of hennosides assessed (Table 2). Because of the uncertainty of measurement tool, $20 \%$ should be added or subtracted to any reading.

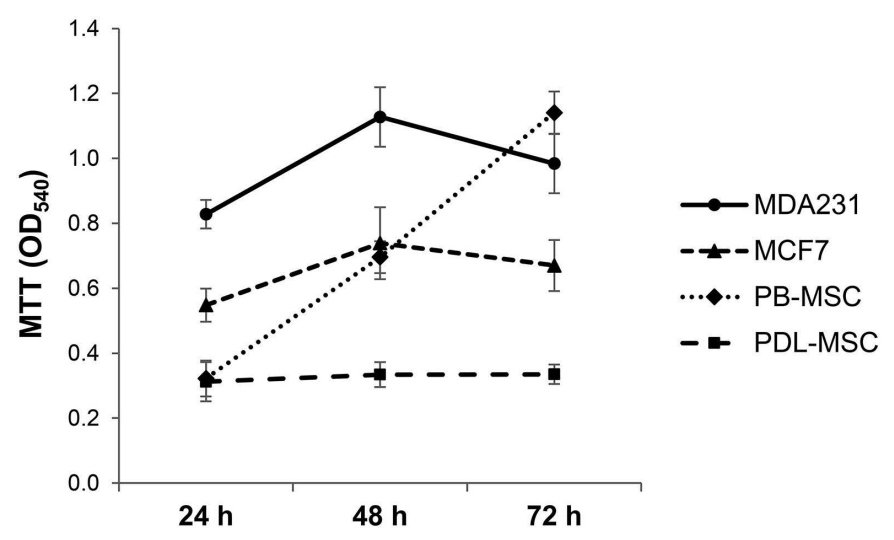

Figure 7. MTT test assayed spontaneous proliferation/viability of human breast cancer cells MDA 231 and MCF-7, and primary human periodontal ligament and peripheral blood mesenchymal stem cells (PDL-MSC and PB-MCS) in short-term cell culture. 
Table 2. Viability of hennoside-treated cells: MTT test.

\begin{tabular}{|c|c|c|c|c|}
\hline & \multirow[b]{2}{*}{$\begin{array}{c}\text { Hennoside } \\
(\mu \mathrm{g} / \mathrm{mL})\end{array}$} & \multicolumn{3}{|c|}{ Relative Viability (\%) } \\
\hline & & $24 \mathrm{~h}$ & $48 \mathrm{~h}$ & $72 \mathrm{~h}$ \\
\hline & & \multicolumn{3}{|c|}{ MDA 231} \\
\hline HA & $\begin{array}{c}0 \\
100\end{array}$ & $\begin{array}{l}100 \\
116\end{array}$ & $\begin{array}{l}100 \\
101\end{array}$ & $\begin{array}{l}100 \\
107\end{array}$ \\
\hline HB & $\begin{array}{c}0 \\
100\end{array}$ & $\begin{array}{l}100 \\
101\end{array}$ & $\begin{array}{c}100 \\
95\end{array}$ & $\begin{array}{l}100 \\
104\end{array}$ \\
\hline \multirow[t]{2}{*}{$\mathrm{HC}$} & $\begin{array}{c}0 \\
100\end{array}$ & $\begin{array}{l}100 \\
109\end{array}$ & $\begin{array}{c}100 \\
95\end{array}$ & $\begin{array}{l}100 \\
105\end{array}$ \\
\hline & & \multicolumn{3}{|c|}{ MCF 7} \\
\hline HA & $\begin{array}{c}0 \\
100\end{array}$ & $\begin{array}{l}100 \\
118\end{array}$ & $\begin{array}{l}100 \\
117\end{array}$ & $\begin{array}{l}100 \\
118\end{array}$ \\
\hline $\mathrm{HB}$ & $\begin{array}{c}0 \\
100\end{array}$ & $\begin{array}{l}100 \\
116\end{array}$ & $\begin{array}{l}100 \\
111 \\
\end{array}$ & $\begin{array}{l}100 \\
114\end{array}$ \\
\hline $\mathrm{HC}$ & $\begin{array}{c}0 \\
100 \\
\end{array}$ & $\begin{array}{c}100 \\
91 \\
\end{array}$ & $\begin{array}{c}100 \\
90 \\
\end{array}$ & $\begin{array}{l}100 \\
116\end{array}$ \\
\hline & & \multicolumn{3}{|c|}{ PDL-MSC } \\
\hline HA & $\begin{array}{c}0 \\
100\end{array}$ & $\begin{array}{c}100 \\
98 \\
\end{array}$ & $\begin{array}{c}100 \\
99 \\
\end{array}$ & $\begin{array}{c}100 \\
88\end{array}$ \\
\hline $\mathrm{HB}$ & $\begin{array}{c}0 \\
100\end{array}$ & $\begin{array}{l}100 \\
104\end{array}$ & $\begin{array}{l}100 \\
107\end{array}$ & $\begin{array}{c}100 \\
92\end{array}$ \\
\hline $\mathrm{HC}$ & $\begin{array}{c}0 \\
100\end{array}$ & $\begin{array}{c}100 \\
95\end{array}$ & $\begin{array}{c}100 \\
99\end{array}$ & $\begin{array}{c}100 \\
83\end{array}$ \\
\hline & & \multicolumn{3}{|c|}{ PB-MSC } \\
\hline HA & $\begin{array}{c}0 \\
100\end{array}$ & $\begin{array}{l}100 \\
107\end{array}$ & $\begin{array}{l}100 \\
102 \\
\end{array}$ & $\begin{array}{c}100 \\
99\end{array}$ \\
\hline $\mathrm{HB}$ & $\begin{array}{c}0 \\
100\end{array}$ & $\begin{array}{l}100 \\
105\end{array}$ & $\begin{array}{l}100 \\
102\end{array}$ & $\begin{array}{c}100 \\
93\end{array}$ \\
\hline $\mathrm{HC}$ & $\begin{array}{c}0 \\
100\end{array}$ & $\begin{array}{l}100 \\
107\end{array}$ & $\begin{array}{l}100 \\
110\end{array}$ & $\begin{array}{c}100 \\
96\end{array}$ \\
\hline
\end{tabular}

MTT reactivity of the cells grown in the cell culture medium without hennosides (control) was set at $100 \%$. The relative viability of cells grown with hennosides is expressed as a percentage of corresponding control. Values are mean of two independent experiments. HA-hennoside A; HB-hennoside B; HC-hennoside C. MDA 231 and MCF 7-human breast cancer cell lines; PDL-MSC—human periodontal ligament mesenchymal stem cells, PB-MSC — human peripheral blood mesenchymal stem cells.

\subsection{Antioxidant Activity of Culture Supernatant of Hennoside-Treated Cells}

A moderate cell type- and incubation time-dependent increase in the concentration of antioxidants (antioxidant capacity) was detected in the culture supernatants of MDA 231 and MCF 7 breast cancer cell line and primary mesenchymal cells (PDL-MSC and PB-MSC) (Figure 8, Table S4). The upward inclination in antioxidant concentration was not followed by the same trend of changes in MTT reactivity. 
a)

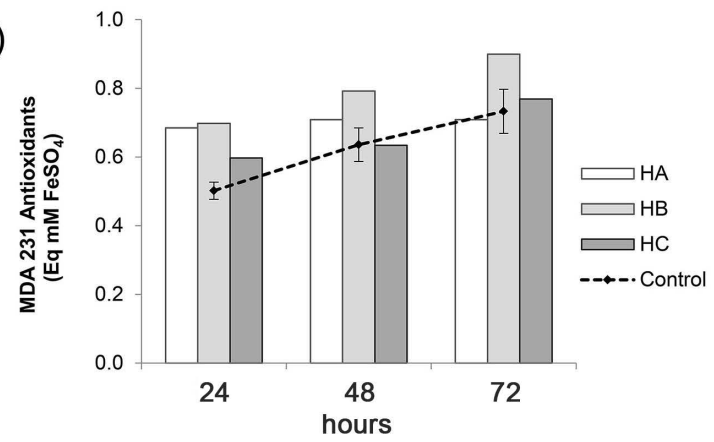

b)

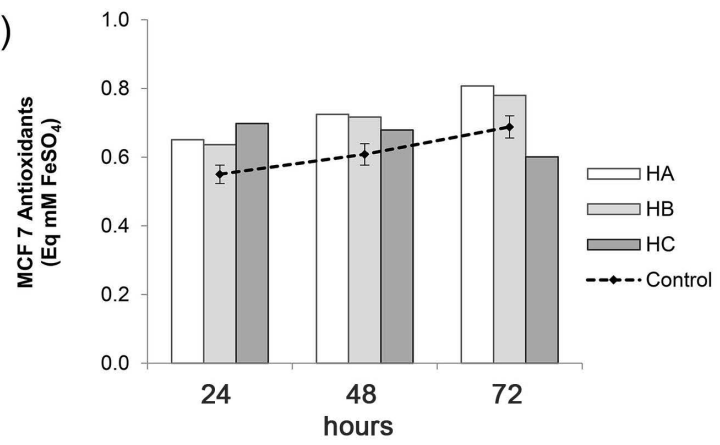

c)

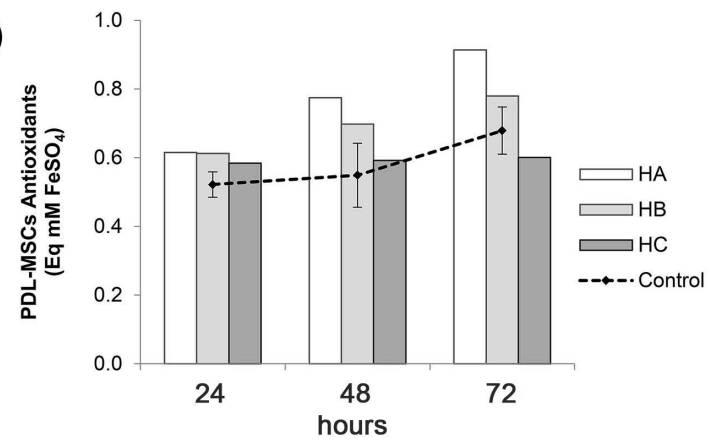

d)

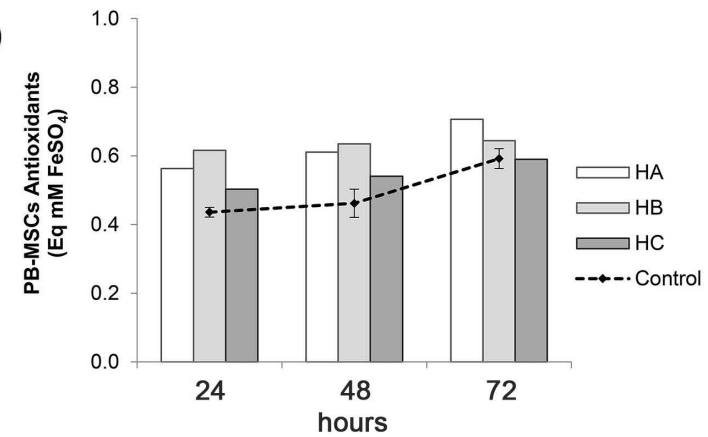

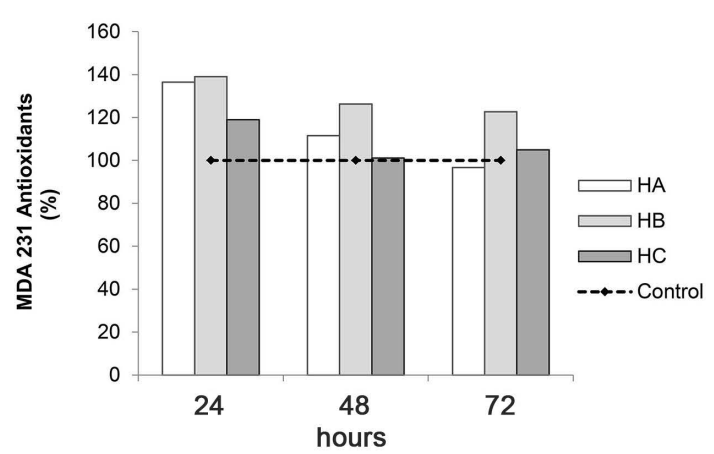
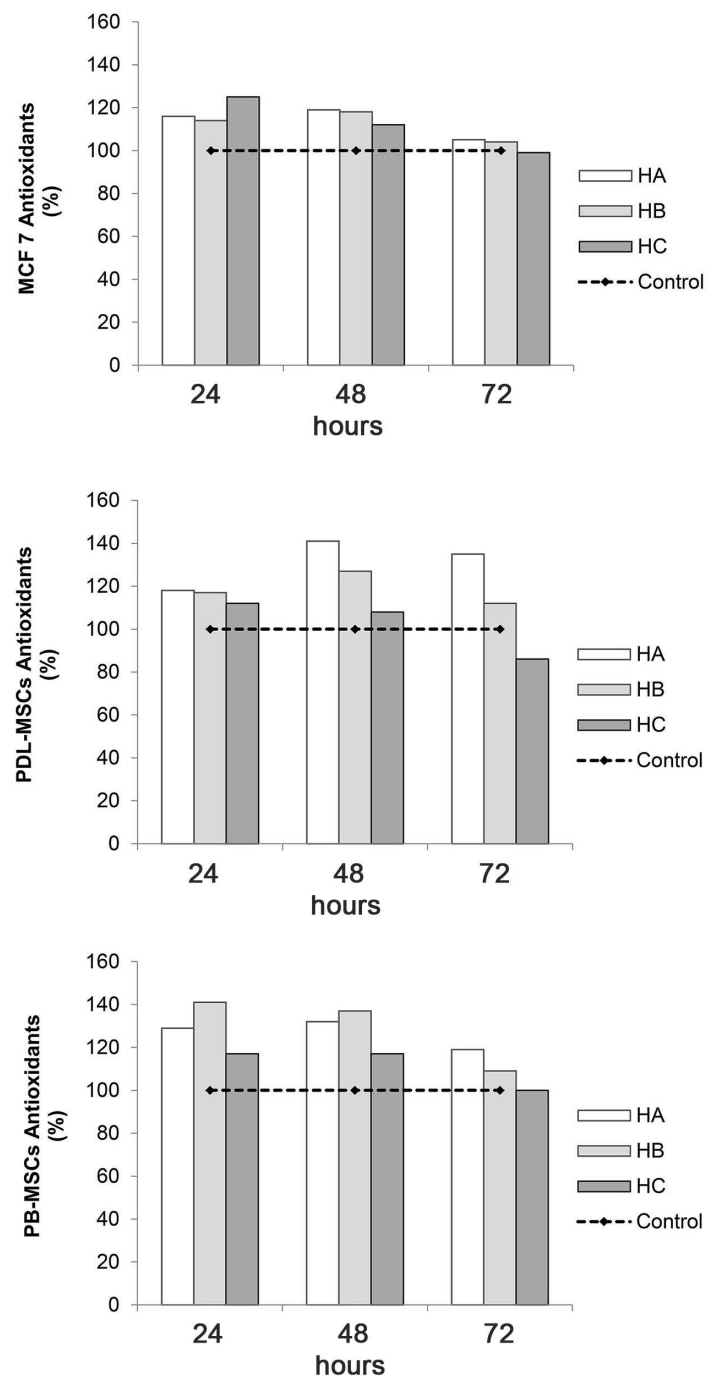

Figure 8. Hennosides at a concentration of $100 \mu \mathrm{g} / \mathrm{mL}$ enhance the concentration of antioxidants in supernatants of human breast cancer cells MDA 231 (a) and MCF-7 (b), and primary human periodontal ligament and peripheral blood mesenchymal stem cells, PDL-MSC (c) and PB-MCS (d) in short-term cell culture. The result of FRAP assay is given as the concentration of antioxidants presented as $\mathrm{mM}$ equivalent to $\mathrm{FeSO} 4$ concentration (mM), and as a percentage of corresponding control. Control (set at $100 \%$ ) is the concentration of antioxidants in supernatants of cells grown without hennosides.

Analysis of breast cancer cell lines showed that a maximal increase in the antioxidants concentration was found in $24 \mathrm{~h}$ culture supernatants of hennoside $\mathrm{A}, \mathrm{B}$ or $\mathrm{C}$ treated MDA 231 cells (36, 39 and 19\% increase for hennoside A, B and C, respectively). A prolonged stimulatory effect was detected only for hennoside $\mathrm{B}$, which increased the level of antioxidants in the 48 and $72 \mathrm{~h}$ MDA 231 cell culture supernatant by approximately $20 \%$. 
The effect of hennosides on the concentration of antioxidants in supernatants of MCF 7 cells was weaker, and the stimulation did not exceed $25 \%$, even in $24 \mathrm{~h}$ cultures.

The maximal stimulatory effect of hennoside A and B (an increase of $41 \%$ and $27 \%$ ) on the antioxidants level in supernatants of PDL-MSC was detected in $48 \mathrm{~h}$ culture. The effect of hennoside A, but not hennoside B was still pronounced in $72 \mathrm{~h}$ cell culture $(35 \%$ stimulation). Hennosides A and B also increased the antioxidant level in the supernatant of PB-MSC, it is just that stimulation, of approximately $30 \%$ and $40 \%$, was pronounced in 24 and $48 \mathrm{~h}$ PB-MSC cultures. The effect of hennoside $\mathrm{C}$ on analyzed primary mesenchymal stem cells was weaker than the effect of hennoside A and B.

\section{Discussion}

From ancient Egypt until today, the use of henna has only expanded all over the world. Nowadays, the main use is cosmetic and for decorative body painting. However, henna possesses curative properties due to the presence of various complex chemical substances of different composition. Each of those chemicals that henna contains, in addition to the well-known lawsone, a widely used hair dye, can exert its own biological effect on the body [14]. Henna is considered safe. Lawsone's position is slightly different: a few studies pointed out that lawsone carries the potential to induce oxidative injury to red blood cells (RBC) with normal Glucose-6-phosphate dehydrogenase (G6PD) activity, and even more so to G6PD-deficient red cells, and acute renal failure was observed due to its nephrotoxic effect $[15,16]$.

To the best of our knowledge, there is a lack of data on the biological effects of hennosides, and we found it to be of interest to explore the redox potential of these isomers using erythrocytes, breast cancer cell lines and primary mesenchymal stem cells, as a model system.

In this study, we reported the ability of hennosides to provoke hemolytic response, and oxidation of hemoglobin to methemoglobin, although higher concentrations $(\geq 500 \mu \mathrm{g} / \mathrm{mL})$ of hennosides are necessary to achieve this pro-oxidative effect. Additionally, a mild hemolysis induced by hennosides dissolved in isotonic $\mathrm{NaCl}$ solution with serum addition was not followed by a change in the color of hemoglobin; the UV-Vis spectra of isolated hemoglobin indicated the protective effect of serum. To substantiate the protective effect of serum, we will quote Kameneva et al. [17]: "The lowest hemolysis was obtained for RBCs, human and bovine, resuspended in serum, plasma, and albumin solutions".

From the results outlined above, we also witnessed the ability of hennosides to induce methemoglobin formation in vitro. Furthermore, the results confirmed the influence of solvent on methemoglobin formation i.e., the presence of serum in the solution dampened the oxidative "pressure" on $\mathrm{Hb}$. The pro-oxidant behavior of hennosides finds its support in the observation presented by McMillan et al. [18] that lawsone (1,4-naphthoquinone) carries the potential to produce oxidant pressure and damage, to rat erythrocytes in vivo. They also reported that hemolytic concentration $(0.5 \mathrm{mM})$ of two 1,4-naphthoquinone derivatives induced significant methemoglobin formation in rat erythrocytes in vitro. The in vitro hemolytic concentration of hennosides $(1.4 \mathrm{mM})$ reported in our work is close to three times as high as in vivo hemolytic concentration of naphthoquinones $(0.5 \mathrm{mM})$.

Moreover, we concluded, based on our results for cytotoxicity, that the assessed concentration $(100 \mu \mathrm{g} / \mathrm{mL})$ of hennoside-treated cells did not reduce the viability of either cancer or MSC cells. However, it is necessary to screen higher concentrations of hennosides for toxic effect on cells.

In the supernatants of hennoside-treated cancer and MSC cells, we confirmed the antioxidant protection at a $100 \mu \mathrm{g} / \mathrm{mL}$ concentration. Another step in evaluating the redox activity of hennosides dissolved in isotonic $\mathrm{NaCl}$ or D'MEM/10\%FCS gave us an estimate that hennosides at $100 \mu \mathrm{g} / \mathrm{mL}$ and higher concentration can act as reducing agents. At this point, we need to emphasize that our estimation of antioxidant activity of hennosides in cell culture supernatants was based only on FRAP assay; ABTS assay has already proved to be inadequate for hennosides in the presence of cell culture medium enriched with serum. 
These differences may be due to various kinds of antioxidants present in the samples which react differently with the radicals used [19] and the known fact that medium supplemented with serum is expected to have appropriately higher antioxidant capacity [20].

As we mentioned earlier, the major constituent of henna plant preparations is lawsone that has mainly been used in the synthesis of a few anticancer drugs, along with henna's chemical breakdown. Although many medical advantages are attributed to lawsone, its transport represents a challenge associated with its hydrophobic nature, which results in poor solubility, poor permeability, low bioavailability and instability in biological systems [21,22]. Conversely, glucosides, although chemically difficult to obtain, are marked by better solubility and delivery into the cell compared to active but unstable lawsone [7], which ultimately directed our interest towards hennosides as constituents.

Current direct information about the pharmacologic activities of hennosides are lacking, due to the difficulties in obtaining them as pure compounds and the misunderstanding regarding the lawsone being the active ingredient of henna. However, it is clear that there is a structural relation between hennosides and lawsone, and the reports on lawsone are indicative of the effects reported in this paper. The first indication concerns the application of henna, which can induce hemolytic anemia. However, phytochemical studies evidenced in henna the presence of hundreds of constituents, several of them specific to the plant. Lawsone is thought to be the causative agent [23], since its administration to rats has been shown to induce a hemolytic response associated with oxidative damage to erythrocytes. However, when isolated erythrocytes were directly exposed to lawsone, no provoked oxidative damage was evidenced, suggesting that lawsone must undergo extra-erythrocytic bioactivation in vivo. A study [18] reported several relevant data, suggesting that lawsone is a weak direct-acting hemolytic agent that does not require extra-erythrocytic metabolism to cause hemotoxicity. These considerations are based on the observation that neither lawsone nor its hydroquininic form (1,2,4-trihydroxynaphthalene) were directly hemolytic or methemoglobinemic, even at high concentrations. Furthermore, lawsone had no effect on erythrocytic GSH (glutathione) levels, whereas its hydroquinonic form induced a modest depletion (approximately 30\%). Therefore, the conclusion of the study is that the hemolytic response to henna could be restricted to individuals with compromised antioxidant defense, as well as a confirmation of the association between the hemolytic effect and the oxidative damages. These data are in accordance with the use of dyeing plants in pigmentation and depigmentation products whose mechanism of action is based on melanin production and antioxidant effects. From a structural point of view, it is necessary to perceive lawsone as the result of equilibrium between the quinonic and the hydroquinonic form through the keto-enolic tautomerism, and it is considered that the antioxidant activity is attributed to the presence of functional phenolic and enolic groups. This structure/activity relation, confirmed by many studies in henna and L. inermis extracts [24], makes it possible to suggest a preference for plant extracts in cosmetics for body art, the treatment of skin causing often local inflammation and dermatitis [25]. In particular, structures of hennosides also possess a keto-enolic tautomerism, but the glucoside form changes radically solubility, biodisponibility and reactivity in favor of further in-deep analysis of the properties here reported.

The main outcome of the results obtained in this study is that hennoside anti- and pro-oxidant activities indicate their potential to act as redox balance regulator. It is known that in inflammation associated with infectious, autoimmune and malignant diseases, a common denominator of body response to stressors is the redox homeostasis; an equilibrium between the production of reactive oxidative species (ROS), signaling molecules that play important roles in cellular physiology and pathophysiology necessary for initiation of multiple defense mechanisms of the body, but can also damage cellular proteins, lipids, and DNA when in excess, and the antioxidant defense system important for resolution of inflammation [26-28]. Although it has for a long time been considered that ROS synthesis and ROS-induced oxidative damage of cells and tissues are harmful, today it is a known fact that their generation (even at low-to-moderate levels) represents an important 
signaling and protection mechanism in infectious and malignant diseases [25,26]. Whether hennoside isomers, as potential therapeutics, will act either as pro- or antioxidant agents depends on their concentration, the molecular substrates they react with, the nutritional status and immunological competence of individuals, as well as the inflammatory milieu in organs and tissues affected by the disease. Therefore, it is necessary to proceed with further investigation to determinate the mechanisms of action of hennosides, and consequently their possible pharmacological use, as well as the safe use of henna products in body art, like temporary tattoos and hair dye [29,30].

\section{Materials and Methods}

\subsection{Plant Material, Authentication}

Leaves from samples of Lawsonia inermis L. were collected in the Shahdad zone of Kerman (Iran) at the end of June, before the flowering period. To collect the leaves in time, it is necessary to follow the withdrawal dates of the Indian monsoon and its relation with the onset of fall precipitation in different parts of Iran. The collected leaves were immediately dried at ordinary temperature using an air flux.

Leaves were identified and authenticated by M. Nicoletti based on morpho-anatomical and histochemical characters. Voucher samples were deposited into the Herbarium at Department of Environmental Biology, Sapienza University of Rome.

\subsection{Sample Preparation}

The dried leaves (20 g) were crushed, powdered and sieved (sieve No. 355) to obtain a uniform powder. Later, the powder was extracted with methanol (100 mL) at ordinary temperature for 2 days and the material was transferred in capped test tubes, gently shaken and then sonicated in a model 3210E-MTH (Branson, Danbury, CT, USA) ultrasonic bath for 45 min [31,32]. The supernatant was filtered through Albet (Barcelona, Spain) qualitative analysis filter paper $(43-38 \mu \mathrm{m})$ and the filtered extract was concentrated under vacuum to dryness to obtain solid amorphous residues. The yield of the obtained dried extract was about $18 \%(w / w)$. The obtained extract was separated by careful column chromatography on silica gel $(400 \mathrm{~g})$, collecting fractions of $10 \mathrm{~mL}$. First, the column was eluted with $20 \mathrm{~mL}$ of n-hexane, and later with n-hexane/ethylacetate 99:1 (w/w), obtaining pure hennosides $\mathrm{A}-\mathrm{C}$ in the fractions $15-25$, with the following yields: hennoside A (10 mg), hennoside C (15 mg), hennoside B (8 mg), in the sequence. The total procedure was repeated three times to obtain the sufficient quantities of pure compounds. The hennosides were identified by their 1H NMR spectra (Varian 400 in CDCl3; Varian, Inc., Palo Alto, CA, USA) (Table 3), as already reported Nicoletti et al. [33].

Table 3. Hennosides: ${ }^{1} \mathrm{H}$ NMR recorded data ${ }^{\mathrm{a}}$.

\begin{tabular}{cccc}
\hline Compound & Hennoside A & Hennoside B & Hennoside C \\
\hline $\mathrm{H}-5$ & $8.00, \mathrm{~d}, \mathrm{~J}=8.1 \mathrm{~Hz}$ & $8.32, \mathrm{~d}, \mathrm{~J}=8.1 \mathrm{~Hz}$ & $7.68, \mathrm{~d}, \mathrm{~J}=8.1 \mathrm{~Hz}$ \\
$\mathrm{H}-6$ & $7.42, \mathrm{t}, \mathrm{J}=8.1 \mathrm{~Hz}$ & $6.96, \mathrm{t}, \mathrm{J}=8.1 \mathrm{~Hz}$ & $7.22, \mathrm{t}, \mathrm{J}=8.1 \mathrm{~Hz}$ \\
$\mathrm{H}-7$ & $7.22, \mathrm{t}, \mathrm{J}=8.1 \mathrm{~Hz}$ & $7.42, \mathrm{t}, \mathrm{J}=8.1 \mathrm{~Hz}$ & $7.24, \mathrm{t}, \mathrm{J}=8.1 \mathrm{~Hz}$ \\
$\mathrm{H}-8$ & $7.07, \mathrm{~d}, \mathrm{~J}=8.1 \mathrm{~Hz}$ & $7.24, \mathrm{~d}, \mathrm{~J}=8.1 \mathrm{~Hz}$ & $7.40, \mathrm{~d}, \mathrm{~J}=8.1 \mathrm{~Hz}$ \\
$\mathrm{H}-3$ & $6.48, \mathrm{~s}$ & $5.87, \mathrm{~s}$ & $6.18, \mathrm{~s}$ \\
$\mathrm{H}-1^{\prime}$ & $4.58, \mathrm{~d}, \mathrm{~J}=6.5 \mathrm{~Hz}$ & $4.72, \mathrm{~d}, \mathrm{~J}=6.5 \mathrm{~Hz}$ & $4.52, \mathrm{~d}, \mathrm{~J}=6.5 \mathrm{~Hz}$ \\
$\mathrm{H}-2^{\prime}-6^{\prime}$ & $3.80-3.26$ & $3.80-3.26$ & $3.80-3.26$ \\
\hline
\end{tabular}

a NMR data recorded on a Varian Mercury instrument operating at $300 \mathrm{MHz}$ (solvent CD3OD). The chemical shifts were expressed using the internal signal of CD2HOD (m5, $3.31 \mathrm{ppm})$ as reference.

\subsection{Antioxidant Capacity Estimation}

Hennosides were diluted in two different solvents $\left(0.9 \% \mathrm{NaCl}\right.$ and $\left.\mathrm{D}^{\prime} \mathrm{MEM} / 10 \% \mathrm{FCS}\right)$ in the following concentrations: 1, 10, 100, $200500,1000 \mu \mathrm{g} / \mathrm{mL}$. The total antioxidant capacity was measured using ferric ion reducing antioxidant power (FRAP) and 2,2'-azinobis(3-ethylbenzothiazoline-6-sulphonic acid (ABTS) de-colorization assay. Additionally, supernatants of the cells co-cultivated with $100 \mu \mathrm{g} / \mathrm{mL}$ hennosides were also analyzed. 


\subsubsection{Ferric-Reducing Antioxidant Power Assay}

FRAP was measured as described by Benzie and Strain [34], with some modifications. A working FRAP solution was prepared by mixing $10 \mathrm{~mL} 300 \mathrm{mM}$ acetate buffer, $\mathrm{pH}$ 3.6; $1 \mathrm{~mL} 10 \mathrm{mM}$ 2,4,6-Tripyridyl-s-triazine; $1 \mathrm{~mL} 20 \mathrm{mM} \mathrm{FeCl}_{3} ; 1.2 \mathrm{~mL} \mathrm{H}_{2} \mathrm{O}$. Undiluted samples $(10 \mu \mathrm{L})$ containing $1,10,100,200,500$ and $1000 \mu \mathrm{g} / \mathrm{mL}$ hennosides $\mathrm{A}, \mathrm{B}$ or $\mathrm{C}$ dissolved in $0.9 \% \mathrm{NaCl}$ or in $\mathrm{D}^{\prime} \mathrm{MEM} / 10 \%$ FCS and cell culture supernatants of different cells grown with $100 \mu \mathrm{g} / \mathrm{mL}$ hennosides $\mathrm{A}, \mathrm{B}$ or C in (see Section 4.7) were added to flat bottom microplates (96-well) together with working FRAP solution $(300 \mu \mathrm{L})$ and incubated at $37^{\circ} \mathrm{C}$ in the dark for $2 \mathrm{~h}$ before reading its absorbance at $540 \mathrm{~nm}$ using a multiplate reader (Victor2V 1420 multilabel HTS counter; Wallac, Finland). Absorbance range was $0.210-0.390$. The increase in absorbance is proportional to the activity of antioxidants in the sample. A calibration curve was made of $\mathrm{FeSO}_{4} \times 7 \mathrm{H}_{2} \mathrm{O}$ with a set of following concentrations $(0.1,0.2,0.4,0.6,0.8$, and $1.0 \mathrm{mM}$, and absorbance range $0.100-0.400)$ and the concentration of antioxidants was expressed as mM equivalent to $\mathrm{FeSO}_{4} \times 7 \mathrm{H}_{2} \mathrm{O}$. Each concentration of hennosides A, B and C was tested in triplicate.

\subsubsection{ABTS Radical Cation Decolorization Assay}

ABTS radical scavenging activity was determined based on the method described by Miller et al. [35], with few modifications. Undiluted samples (10 $\mu \mathrm{L})$ of 1, 10, 100, 200, 500, and $1000 \mu \mathrm{g} / \mathrm{mL}$ of hennosides $\mathrm{A}, \mathrm{B}$ and $\mathrm{C}$ in $0.9 \% \mathrm{NaCl}$ or 10 times diluted samples $(10 \mu \mathrm{L})$ containing the same concentration of hennosides but diluted in $\mathrm{D}^{\prime} \mathrm{MEM} / 10 \% \mathrm{FCS}$ were mixed with $290 \mu \mathrm{L}$ ABTS solution (ABTS•+ radical cation formed by chemical oxidation of $5 \mathrm{~mL} 1.98 \mathrm{mM}$ ABTS with $88 \mu \mathrm{L} 10.23 \mathrm{mM}$ potassium peroxydisulfate). After incubation for $15 \mathrm{~min}$ at $37^{\circ} \mathrm{C}$, the absorbance of the mixture was measured in a multiplate reader (Victor2V 1420 multilabel HTS counter; Wallac, Finland) at $405 \mathrm{~nm}$. Absorbance range was $0.100-0.250$. The extent of ABTS $\bullet+$ decrease in absorbance is proportional to the activity of antioxidants in each sample. A calibration curve was made of Trolox (6-hydroxy2,5,7,8-tetramethylchroman-2-carboxylic acid), water soluble vitamin E analog, (0.05, 0.1, $0.2,0.3,0.4,0.5$ and $0.6 \mathrm{mM}$, and absorbance range $0.560-0.040$ ) and the concentration of antioxidants was expressed as $\mathrm{mM}$ equivalent to Trolox. Each concentration of hennosides $\mathrm{A}, \mathrm{B}$ and $\mathrm{C}$ was tested in triplicate.

\subsection{In Vitro Erythrocyte Lysis}

Human erythrocyte samples were obtained from the Institute for Transfusiology and Hemobiology, Military Medical Academy, Belgrade, Serbia. Erythrocytes were isolated from buffy coat on the same day of collection. Anonymous buffy coats were obtained from healthy volunteer blood donors, and the bridge to donor is broken. The cells were already labeled as waste.

Experiment was carried out by addition of hennosides A, B and C $(200 \mu \mathrm{L})$ in the concentration range between $1 \mathrm{ng} / \mathrm{mL}-1 \mathrm{mg} / \mathrm{mL}$, dissolved in $0.9 \% \mathrm{NaCl}$ or $0.9 \% \mathrm{NaCl}$ containing $10 \%$ FCS (NaCl-FCS), to $20 \mu \mathrm{L}$ of erythrocytes, previously washed to remove the plasma and leukocytes, and re-suspended in $0.9 \% \mathrm{NaCl}$ to an $8 \%$ hematocrit. The assay was performed in 96 well, U-bottom shaped, microtiter plate. Each concentration of hennoside A, B and C was tested in triplicate. For preparing the stock solution $(5 \mathrm{mg} / \mathrm{mL})$ each hennoside was dissolved in DMSO. To assess the hemolytic effect of DMSO on erythrocytes, the erythrocytes were incubated with corresponding dilution of DMSO. After the incubation time of $90 \mathrm{~min}$ at $37^{\circ} \mathrm{C}$, and centrifugation for $10 \mathrm{~min}$ at $2500 \mathrm{rpm}$ (Megafuge 1.0R Heraeus, Landshut, Germany), $\mathrm{OD}_{540}$ value (absorbance at $540 \mathrm{~nm}$; corresponds one of absorption maxima of oxyhemoglobin) of supernatant was measured in a multiplate reader (Victor2V 1420 multilable HTS counter; Wallac, Finland.

\subsection{VIS Spectroscopy of Hemoglobin}

The hennosides $\mathrm{A}, \mathrm{B}$ and $\mathrm{C}$ in the concentration range between $1 \mathrm{ng} / \mathrm{mL}-1 \mathrm{mg} / \mathrm{mL}$ were incubated with outdated bovine hemoglobin $(\mathrm{bHb})$ (erythrocytes derived from cattle 
slaughterhouse, as described by Drvenica et al. [36], dissolved in $0.9 \% \mathrm{NaCl}$ or $0.9 \mathrm{NaCl}$ containing $10 \%$ FCS (NaCl-FCS). After the incubation period of $90 \mathrm{~min}$ at $37^{\circ} \mathrm{C}$, the $\mathrm{OD}_{630}$ value, which is the methemoglobin characteristic absorption peak, was obtained on microplate reader. Effect of hennosides $(0.5 \mathrm{mg} / \mathrm{mL}$ ) on the absorption spectra (wavelength range between 390 and $750 \mathrm{~nm})$ of $\mathrm{bHb}(10 \mu \mathrm{M})$ was analyzed with Ultrospec 3300 pro UV-VIS spectrophotometer (Amersham Biosciences, Little Chalfont, UK).

\subsection{MTT (Thiazolyl Blue Tetrazolium Bromide) Assay}

Human breast carcinoma cell lines MDA231 and MCF7 (ATCC, Manassas, VA, USA), human peripheral blood derived mesenchymal stem cells (PB-MSCs) [37] and human periodontal ligament derived mesenchymal stem cells (PDL-MSCs) [38] were cultured in D'MEM cell growth medium (Sigma-Aldrich, St. Louis, MO, USA) enriched with 10\% foetal bovine serum (FCS) (PAA Laboratories GmbH, Pasching, Austria) (D'MEM-10\% FCS). A passage number of the MSCs, used in the experiment, was less than 10.

Cells were seeded in $25 \mathrm{~cm}^{2}$ plastic tissue culture flasks at a concentration of $2 \times 10^{5}$ cells $/ \mathrm{mL}$ and incubated at $37^{\circ} \mathrm{C}$ with humidified atmosphere of $5 \% \mathrm{CO}_{2}$. The cells were maintained by replacing the growth medium every 2 to 3 days. After having reached $80-90 \%$ of confluence, the cells were detached by $0.25 \%$ trypsin-EDTA solution (PAA) and re-plated at a seeding density appropriate for the cell line.

MTT test was performed to analyze the viability of cells used in this study [39]. In brief, $1 \times 10^{4}$ cells in D'MEM-10\%FCS solution/well were seeded in 96-well plates and incubated for $24 \mathrm{~h}$. After adhesion, the incubated cells were treated with hennoside A, $B$ and $C$, respectively, and diluted in $\mathrm{D}^{\prime} \mathrm{MEM} / 10 \% \mathrm{FCS}$ to reach the final concentration of $100 \mu \mathrm{g} / \mathrm{mL}$ per well (the final volume per well was $100 \mu \mathrm{L}$ ). Cells in $100 \mu \mathrm{L} \mathrm{D}^{\prime} \mathrm{MEM}$ $10 \%$ FCS suspension was used as a control for the cell baseline proliferation level. The incubation was continued for 24,48 and $72 \mathrm{~h}$. After incubation, $10 \mu \mathrm{L}$ of MTT (thiazolyl blue tetrazolium bromide, i.e., 3-(4,5-dimethylthiazol-2-yl)-2,5-diphenyltetrazolium bromide) (Sigma-Aldrich, USA) solution ( $5 \mathrm{mg} / \mathrm{mL}$ in PBS) was applied and incubation was carried out at $37^{\circ} \mathrm{C}$ for $3 \mathrm{~h}$ in a dark place. The medium was then replaced with $100 \mu \mathrm{L}$ of $10 \%$ SDS containing $10 \mathrm{mM} \mathrm{HCl}$ to dissolve the formazan crystals. The solubilized formazan dye product of each well was quantified spectrophotometrically at $540 \mathrm{~nm}$ with a 96-well plate reader and $620 \mathrm{~nm}$ was used as the reference wavelength. Blanks containing only culture medium, MTT and SDS were used to correct the absorbance. Relative MSC viability in D'MEM/10\%FCS, as an index to MSC viability, was set at $100 \%$.

\subsection{Antioxidant Activity in the Cell Culture Supernatants}

Human breast carcinoma cell lines MDA231 and MCF7, human peripheral bloodderived mesenchymal stem cells (PB-MSCs) were prepared and cultured with and without $100 \mu \mathrm{g} / \mathrm{mL}$ for 24,48 and $72 \mathrm{~h}$ in 96 well microtiter plates, as described in the Section 4.6. After the culture time, microtiter plates were centrifuged $\left(10 \mathrm{~min}, 2500 \mathrm{rpm}, 22^{\circ} \mathrm{C}\right)$, and supernatant was collected. The antioxidant activity of the cell culture supernatants was determined by FRAP assay as described in Section 4.3.1.

\subsection{Statistical Analysis}

Graphs were created with Microsoft Office Excel software (Microsoft Corporation, USA). In the tables in the Supplementary Materials, the results are expressed as means with standard deviation (SD).

\section{Conclusions}

The results of this study delineated threes isomers of hennosides, the main constituents of Lawsonia inermis (henna tree), as redox active compounds. They were able to provoke hemolytic response, and oxidation of hemoglobin, although higher concentrations $(\geq 500 \mu \mathrm{g} / \mathrm{mL}$ ) of hennosides were necessary to achieve this pro-oxidative effect. Antioxidant activity of hennosides at concentration $\geq 100 \mu \mathrm{g} / \mathrm{mL}$ was confirmed by FRAP and 
ABTS assays. At $100 \mu \mathrm{g} / \mathrm{mL}$ concentration, hennosides did not influence the viability of human breast cancer cell lines MDA231 and MCF-7 and primary human peripheral bloodand periodontal ligament-mesenchymal stem cells, they induced a moderate increase in concentration of antioxidants in the cell culture supernatants instead.

Even though we have just scratched the surface of the biological activity of glucosides/hennosides, this research gives a first insight into the redox activity of hennoside extracts in vitro. Hennosides are examples of substances that have yet to be tested to ascertain what they can do and how they can regulate the redox potential of cells. It is noteworthy to quote Glasauer and Chandel [25] that "pro-oxidant cancer therapy makes an interesting area of study nowadays".

Supplementary Materials: The following are available online at https:/ /www.mdpi.com/2223-7 747/10/2/237/s1, Table S1: Antioxidant activity of hennosides, Table S2: Effect of hennosides on the erythrocyte lysis, Table S3: Effect of hennoside on methemoglobin formation studied based on increasing in hemoglobin $\mathrm{OD}_{630}$ values, Table S4: Effect of hennosides on concentration of antioxidants in cell culture supernatant.

Author Contributions: All authors contributed equally to this work (participated in the study design, data collection and analysis, and writing of the manuscript). All authors have read and agreed to the published version of the manuscript.

Funding: This research was funded by the Ministry of Education, Science and Technological Development of Republic of Serbia (grant number 451-03-68/2020-14/200015).

Institutional Review Board Statement: Ethical review and approval were waived for this study due to performing the study using waste material-anonymized buffy coats from healthy volunteer blood donors.

Informed Consent Statement: Heathy blood donors' consent was waived due to performing the study using waste material-anonymized buffy coats.

Data Availability Statement: The datasets used and analyzed during the current study are available from the corresponding author on reasonable request.

Conflicts of Interest: No potential conflict of interest has been reported by the authors.

\section{References}

1. Semwal, R.B.; Semwal, D.K.; Combrinck, S.; Cartwright-Jones, C.; Viljoen, A. Lawsonia inermis L. (henna): Ethnobotanical, phytochemical and pharmacological aspects. J. Ethnopharmacol. 2014, 155, 80-133. [CrossRef] [PubMed]

2. Carroll, L.; Anderson, R. Body piercing, tattooing, self-esteem, and body investment in adolescent girls. Adolescence 2002, 37, 627-637. [PubMed]

3. Dweck, A.C. Natural ingredients for colouring and styling. Int. J. Cosmet. Sci. 2002, 24, 287-302. [CrossRef] [PubMed]

4. Food and Drug Administration (FDA). Temporary Tattoos \& Henna/Mehndi. Available online: https://www.fda.gov/cosmetics/ cosmetic-products/temporary-tattoos-hennamehndi-and-black-henna-fact-sheet (accessed on 10 December 2020).

5. FDA, Food and Drug Administration. Color Additives Permitted for Use in Cosmetics. Available online: https://www.fda.gov/ cosmetics/cosmetic-ingredient-names/color-additives-permitted-use-cosmetics (accessed on 10 December 2020).

6. Kapadia, G.J.; Fayez, M.B.E.; Sethi, M.L. Hennosides, the primary glycosidic constituents of henna. J. Nat. Prod. Lloydia 1969, 32, 523.

7. Gallo, F.R.; Multari, G.; Palazzino, G.; Pagliuca, G.; Majid Majd Zadeh, S.; Prosper Cabral Nya, B.; Nicoletti, M. Henna through the centuries: A quick HPTLC analysis proposal to check henna identity. Rev. Bras. De Farmacogn. 2014, 24, 133-140. [CrossRef]

8. Nicoletti, M.; Petitto, V.; Gallo, F.R.; Multari, G.; Federici, E.; Palazzino, G. The modern analytical determination of botanicals and similar novel natural products by the HPTLC fingerprint approach. In Studies in Natural Products Chemistry; Rahman, A., Ed.; Elsevier: Amsterdam, The Netherlands, 2012; Volume 37, pp. 217-258.

9. Anonymous. Papyrus Ebers. Calif. State J. Med. 1912, 19, 219.

10. Zijlstra, W.G.; Buursma, A.; Meeuwsen-van der Roest, W.P. Absorption spectra of human fetal and adult oxyhemoglobin, de-oxyhemoglobin, carboxyhemoglobin, and methemoglobin. Clin. Chem. 1991, 37, 1633-1638. [CrossRef]

11. Sherif, S.M.; Amal, E.I. Analysis of retinal b-wave by fourier transformation due to ammonia exposure and the role of blood erythrocytes. Rom. J. Biophys. 2010, 20, 269-281.

12. Hanson, E.K.; Ballantyne, J. A blue spectral shift of the hemoglobin Soret band correlates with the age (time since deposition) of dried bloodstains. PLoS ONE 2010, 5, e12830. [CrossRef] 
13. Kukolj, T.; Trivanović, D.; Djordjević, I.O.; Mojsilović, S.; Krstić, J.; Obradović, H.; Janković, S.; Santibanez, J.F.; Jauković, A.; Bugarski, D. Lipopolysaccharide can modify differentiation and immunomodulatory potential of periodontal ligament stem cells via ERK1,2 signaling. J. Cell. Physiol. 2018, 233, 447-462. [CrossRef]

14. Duke, J.A. Database of Biologically Active Phytochemicals and Their Activity; eBook; CRC Press: Boca Raton, FL, USA, 2020. [CrossRef]

15. Kök, N.; Ertekin, M.V.; Ertekin, V.; Avci, B. Henna (Lawsonia inermis Linn.) induced haemolytic anaemia in siblings. Int. J. Clin. Pract. 2004, 58, 530-532. [CrossRef] [PubMed]

16. Raupp, P.; Hassan, J.A.; Varughese, M.; Kristiansson, B. Henna causes life threatening hemolysis in glucose-6-phosphate dehydrogenase deficiency. Arch. Dis. Child. 2001, 85, 411-412. [CrossRef] [PubMed]

17. Kameneva, M.V.; Antaki, J.F.; Yeleswarapu, K.K.; Watach, M.J.; Griffith, B.P.; Borovetz, H.S. Plasma protective effect on red blood cells exposed to mechanical stress. ASAIO J. 1997, 43, M571-M575. [CrossRef] [PubMed]

18. McMillan, D.C.; Sarvate, S.D.; Oatis, J.E., Jr.; Jollow, D.J. Role of oxidant stress in lawsone-induced hemolytic anemia. Toxicol. Sci. 2004, 82, 647-655. [CrossRef]

19. Shah, P.; Modi, H.A. Comparative study of DPPH, ABTS and FRAP assays for determination of antioxidant activity. Int. J. Res. Appl. Sci. Eng. Technol. 2015, 3, 636-641.

20. Lewinska, A.; Wnuk, M.; Slota, E.; Bartosz, G. Total anti-oxidant capacity of cell culture media. Clin. Exp. Pharmacol. Physiol. 2007, 34, 781-786. [CrossRef]

21. López López, L.I.; Flores, N.; Daniel, S.; Silva Belmares, S.; Sáenz Galindo, A. Naphthoquinones: Biological properties and synthesis of lawsone and derivatives-A structured review. Vitae 2014, 21, 248-258.

22. Chaudhary, G.; Goyal, S.; Poonia, P. Lawsonia inermis Linnaeus: A phytopharmacological review. Int. J. Pharm. Sci. Drug Res. 2010, 2, 91-98. Available online: https://ijpsdr.com/index.php/ijpsdr/article/view/89/77 (accessed on 10 December 2020).

23. Zinkham, W.H.; Oski, F.A. Henna: A potential cause of oxidative hemolysis and neonatal hyperbilirubinemia. Pediatrics 1996, 97, 707-709.

24. Das, D.; Samanta, D.; Banerjee, R.; Sinha, S.; Mallick, B.; Ganguli, S.; Roy, D. Insights into the phytochemical potential of Lawsonia inermis L. for future small molecule based therapeutic applications. Review. Int. Res. J. 2020, 11, 1-7. [CrossRef]

25. Matulich, J.; Sullivan, J. A temporary henna tattoo causing hair and clothing dye allergy. Contact Dermat. 2005, 53, 33-36. [CrossRef] [PubMed]

26. Glasauer, A.; Chandel, N.S. Targeting antioxidants for cancer therapy. Biochem. Pharmacol. 2014, 92, 92-101. [CrossRef] [PubMed]

27. Dharmaraja, A.T. Role of Reactive Oxygen Species (ROS) in Therapeutics and Drug Resistance in Cancer and Bacteria. J. Med. Chem. 2017, 60, 3221-3240. [CrossRef] [PubMed]

28. Bar-Or, D.; Bar-Or, R.; Rael, L.T.; Brody, E.N. Oxidative stress in severe acute illness. Redox Biol. 2015, 4, 340-345. [CrossRef]

29. Jovanovic, D.L.; Slavkoviv-Jovanovic, M.R. Allergic contact dermatitis from temporary henna tattoo. J. Dermatol. 2009, 36, 63-65. [CrossRef]

30. Lamchahab, F.-Z.; Guerrouj, B.; Benomar, S.; Ait Ourhroui, M.; Senouci, K.; Hassam, B.; Benzekri, L. Henna symbolic tattoo and real dermatitis. Arch. Pediatr. 2011, 18, 653-656. [CrossRef]

31. Putzbach, K.; Rimmer, C.A.; Sharpless, K.; Wise, S.A.; Sander, L.C. Determination of bitter orange alkaloids in dietary supplement Standard Reference Materials by liquid chromatography with atmospheric-pressure ionization mass spectrometry. Anal. Bioanal. Chem. 2007, 389, 197-205. [CrossRef]

32. Jin, W.; Ge, R.L.; Wei, Q.J.; Bao, T.Y.; Shi, H.M.; Tu, P.F. Development of high-performance liquid chromatographic fingerprint for the quality control of Rheum tanguticum Maxim. ex Balf. J. Chromatogr. A 2006, 1132, 320-324. [CrossRef]

33. Nicoletti, M.; Frezza, C.; Tomassini, L.; Toniolo, C.; Bianco, A. Detection of picramic acid and picramate in henné products by NMR Spectroscopy. Nat. Prod. Res. 2018, 33, 2073-2078. [CrossRef]

34. Benzie, I.F.; Strain, J.J. Ferric reducing/antioxidant power assay: Direct measure of total antioxidant activity of biological fluids and modified version for simultaneous measurement of total antioxidant power and ascorbic acid concentration. Methods Enzymol. 1999, 299, 15-27. [CrossRef]

35. Miller, N.J.; Rice-Evans, C.; Davies, M.J.; Gopinathan, V.; Milner, A. A novel method for measuring antioxidant capacity and its application to monitoring the antioxidant status in premature neonates. Clin. Sci. 1993, 84, 407-412. [CrossRef] [PubMed]

36. Drvenica, I.; Stančić, A.; Kalušević, A.; Marković, S.; Maksimović, J.D.; Nedović, V.; Bugarski, B.; Ilić, V. Maltose-mediated long-term stabilization of freeze-and spray-dried forms of bovine and porcine hemoglobin. J. Serb. Chem. Soc. 2019, 84, 1105-1117. [CrossRef]

37. Trivanović, D.; Kocić, J.; Mojsilović, S.; Krstić, A.; Ilić, V.; Djordjević, I.O.; Santibanez, J.F.; Jovcić, G.; Terzić, M.; Bugarski, D. Mesenchymal stem cells isolated from peripheral blood and umbilical cord Wharton's jelly. Srp. Arh. Celok. Lek. 2013, 141, 178-186. [CrossRef]

38. Miletić, M.; Mojsilović, S.; Okić Đorđević, I.; Kukolj, T.; Jauković, A.; Santibañez, J.F.; Jovčić, G.; Bugarski, D. Mesenchymal stem cells isolated from human periodontal ligament. Arch. Biol. Sci. 2014, 66, 261-271. [CrossRef]

39. Kocić, J.; Santibañez, J.F.; Krstić, A.; Mojsilović, S.; Ilić, V.; Bugarski, D. Interleukin-17 modulates myoblast cell migration by inhibiting urokinase type plasminogen activator expression through p38 mitogen-activated protein kinase. Int. J. Biochem. Cell Biol. 2013, 45, 464-475. [CrossRef] 